\title{
DO SATISFIED CELLAR DOOR VISITORS WANT TO REVISIT? LINKING PAST KNOWLEDGE AND CONSUMPTION BEHAVIORS TO SATISFACTION AND INTENTION TO RETURN
}

\author{
GIRISH PRAYAG, * MARTA DISEGNA, $\dagger$ AND JOHAN BRUWER $\$$ \\ *Department of Management, Marketing and Entrepreneurship, University of Canterbury, \\ Christchurch, New Zealand \\ $\dagger$ Department of Accounting, Finance and Economics, Faculty of Management, Bournemouth University, \\ Bournemouth, UK \\ \$Ehrenberg-Bass Institute for Marketing Science, UniSA Business School, University of South Australia, \\ Adelaide, Australia
}

\begin{abstract}
This study evaluates the main determinants of wine tourists' intention to revisit the winery cellar door. The proposed tourist behavior model suggests that past wine-related knowledge and behaviors as well as motivation affect satisfaction with the cellar door visit. The model suggests that actual behavior at the cellar door (number of bottles bought and amount of money spent) is dependent on the previously mentioned factors. A survey of wine tourists in the Barossa Valley, Australia, led to 676 useable questionnaires. The results of a binary logistic model show that only monthly household expenditure on wine consumption and the motive of tasting wine predict satisfaction with the cellar door visit. A negative binomial model shows that the probability to buy more bottles at the winery increases if the visitor is from Australia, satisfied with the visit, has tasted wine at the cellar door, is younger, spends more on monthly household consumption of wine, and was primarily visiting to buy wine. However, intention to revisit is predicted only by satisfaction, awareness of the winery before the visit, motives of buying and tasting wine, and some sociodemographic characteristics. Implications for the management of visitor behavior and the cellar door experience are also discussed.
\end{abstract}

Key words: Wine tourism; Motivation; Satisfaction; Knowledge; Past behavior

Address correspondence to Girish Prayag, Associate Professor, Department of Management, Marketing and Entrepreneurship, University of Canterbury, Private Bag 4800, Christchurch 8140, New Zealand. Tel: +64 33642987 ext. 94082; E-mail: girish.prayag@canterbury.ac.nz 


\section{Introduction}

The wine buying decision of the wine tourist is a complex process that involves a myriad of cognitive and affective factors. The importance of cognitive factors such as motivation (Alant \& Bruwer, 2004; Byrd et al., 2016), food and wine involvement (Sparks, 2007), and expectations (Charters et al., 2009), as well as affective factors such as anticipated emotions (S. Lee et al., 2017) and satisfaction (Chen, Bruwer, et al., 2016; Gill et al., 2007) on this process has been established in previous studies. However, with a few exceptions (S. Lee et al., 2017; Sparks, 2007), the influence of past winerelated knowledge and behaviors on satisfaction and behavioral intentions has not been examined. The visit of wine tourists to cellar doors offers wineries an opportunity to generate and/or reinforce loyalty intentions among visitors (Alant \& Bruwer, 2010; Chen, Goodman, et al., 2016; Fountain et al., 2008). Yet several studies assume that satisfaction can be used to predict intentions to return of wine tourists accurately (Chen, Bruwer, et al., 2016). On the other hand, Dolnicar et al. (2015) challenged the relationship between satisfaction and intention to return on the premise of conceptual, methodological, and response bias concerns in existing studies, while McKercher and Tse (2012) found no correlation between intention to return and actual repeat visitation rates.

To date, there is no conclusive evidence that previous knowledge and behaviors related to wine consumption will affect tourist satisfaction at the cellar door and that they will return to the same winery. More importantly, existing tourist behavior models in the wine tourism literature (Chen, Bruwer, et al., 2016; Gill et al., 2007) omit past behavior as an important predictor of postconsumption behaviors. This omission poses a significant threat to the future of wineries that are dependent on both repeat visitation at the cellar door and repeat purchase of their wines in the retail sector to survive (Byrd et al., 2016). In fact, previous studies confirm that wine purchasing decisions at the cellar door are quite dependent, not only on the quality of the wine purchased, but also on the service experience at the cellar door (Bruwer et al., 2013). Hence, understanding both previsit and on-site behaviors of wine tourists are important activities that shape managerial strategies of cellar doors in their quest for growth and survival.

Based on the above knowledge gaps, the two main research objectives of this study are to (i) identify the influence of past knowledge and behaviors with respect to wine consumption on behaviors of wine tourists at the cellar door, and (ii) examine the influence of previsit consumption behaviors, consumption at the cellar door, and visit satisfaction on intention to revisit the cellar door. Three different nonlinear regression models have been adopted to describe the above relationships and to identify the factors that mainly affect winery experience satisfaction, actual wine consumption behavior, and future behavioral intention. The correct identification of these factors is fundamental in driving the creation of adequate future managerial and marketing strategies and policies. As such, the theoretical contributions of this study to the wine tourism and marketing literatures are threefold. First, by examining the influence of past knowledge and behaviors on satisfaction and consumption behaviors at the cellar door, existing tourist behavior models in wine tourism (Chen, Bruwer, et al., 2016; Gill et al., 2007; S. Lee et al., 2017; Sparks, 2007) are extended by showing that awareness of the winery and its products as well as behaviors such as household consumption of wine are influential in shaping wine consumption at the cellar door. Second, insights into the psychological mechanisms (motivation, past purchase, satisfaction, and number of wines tasted, etc.) underlying visitors' decision to revisit a winery and the identification of the most important predictors of this decision are critical for the success and survival of wineries.

These insights are particularly important given that previous wine tourism research is limited in its understanding of the decision-making processes involved in wine tourists' visit to a cellar door (S. Lee et al., 2017). Third, by employing a negative binomial model for predicting the number of wine bottles bought at the cellar door, a methodological contribution is offered to address Dolnicar et al.'s (2015) concerns with respect to the relationship between satisfaction and actual behavior. This robust predictive technique has been mainly employed in the tourism literature to predict behaviors of hosts in peer-to-peer rental accommodations (Liang et al., 2017), improvements in perceptions 
of coastal park attributes on recreational demand (Wang et al., 2017), and length of stay of senior tourists (Alén et al., 2014) but so far has received no attention in the wine tourism literature.

\section{Literature Review and Hypotheses Development}

\section{Tourist Behavior Models in Wine Tourism}

"Wine tourism is a relatively fledgling industry sector facing a number of important economic development issues. One such issue is the industry's ability to foster sustainable revenue from small and medium wineries" (Byrd et al., 2016, p. 19). The revenue of wineries is dependent on visitation to the cellar door by both domestic and international visitors. Therefore, it is of no surprise that several behavioral models predicting satisfaction and loyalty of wine tourists exist. For example, Gill et al. (2007) showed that overall satisfaction mediates the relationship between perceived value and behavioral intentions of consumers. Chen, Goodman, et al. (2016) evaluated a behavioral model that examines the role of hedonic and utilitarian shopping value, monetary value perceptions in predicting cellar door visitors' overall satisfaction, and loyalty intentions. They show significant and positive relationships between hedonic and monetary value and satisfaction as well as loyalty. S. Lee et al. (2017) examined the influence of experience with a wine tour and involvement toward wine tourism on several cognitive and affective factors, including past behavior in predicting behavioral intentions.
However, their results showed no significant relationship between past behavior and behavioral intentions. Sparks (2007) examined the influence of concepts such as food and wine involvement, core wine experience, attitude towards past wine experiences, and emotional attitude on intention to take a wine trip. Her results show that attitude towards past wine experiences has a direct effect on intention to visit a wine region in the next 12 months.

While these tourist behavior models are informative in understanding factors that predict behavioral intentions, they do not evaluate the influence of past behavior on either satisfaction or consumption behaviors at the cellar door. Based on Perugini and Bagozzi's (2001) model of goal-directed behavior (MGB), which offers an expansion and deepening of Ajzen's (1991) theory of planned behavior (TPB), we propose (Fig. 1) that visitors' motivational process, affective process, and past behavior can more accurately predict their decision-making processes (S. Lee et al., 2017). The MGB, when applied to wine tourism, has shown high predictive validity and usefulness (S. Lee et al., 2017)

Our proposed model posits that past knowledge and behaviors, motivation, and visitor characteristics influence satisfaction at the cellar door (H1). In turn these factors influence actual consumption behavior at the cellar door, such as number of wine bottles bought (H2), thereby linking past behavior with present or actual behavior. We also posit that past knowledge, motivation, visitor characteristics, satisfaction, and actual behavior can predict

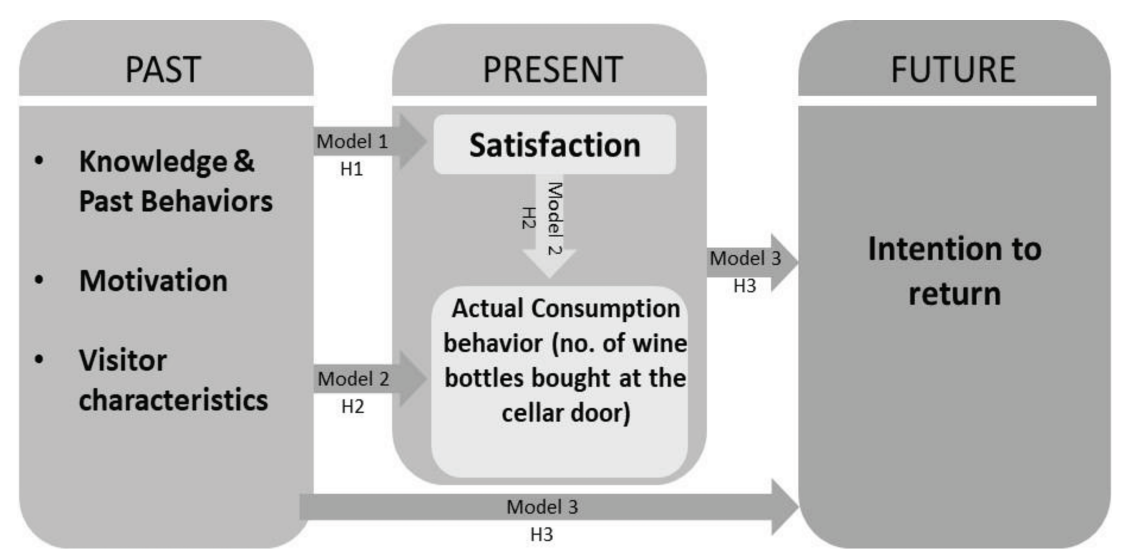

Figure 1. Conceptual model linking past and present behavior to future behavior. 
intention to revisit the cellar door (H3), thereby linking present to future behavior. In this way, the proposed model examines the decision-making processes of wine tourists holistically by highlighting linkages between past, present, and future behaviors.

\section{Past Knowledge and Behaviors, Motivation, Visitor Characteristics, and Satisfaction}

The wine tourist is "someone who feels a need to 'connect' with the origin of the product through visitation of the location (wine region) where wine is produced" (Bruwer et al., 2018). Despite tourism studies showing that previous experience and the possession of knowledge about a tourist destination and its tourism products and services are logically associated with the repeat visitor dynamic in wine tourism (Bruwer et al., 2012; Chen, Bruwer, et al., 2016), the evidence on this relationship is contradictory. For example, Alant and Bruwer (2010) showed that cellar door visitors seek information about the region and its wines before and during a visit. Moreover, regular wine consumption is strongly associated with wine tourism activity factors (Bruwer et al., 2012), and involvement in food and wine increases the visitor's intention to visit a winery (Sparks, 2007). Yet S. Lee et al. (2017) could not establish the influence of past behavior on behavioral intentions in a wine tourism context. As such, there is a need for studies that evaluate how past wine-related knowledge and behaviors impact satisfaction and actual behaviors at the cellar door.

The "vernacular relationship" among the needs, desires, and wants of consumers, recognized by Belk et al. (2003, p. 328), also illuminates their essential differences. Desires are more linked to the consumer's imagination while needs are of a more categorical nature. In the wine tourism literature, this relationship has been examined through the lenses of hedonic pursuits (e.g., Bruwer \& Alant, 2009) and push-pull motivations (Bruwer et al., 2018). In terms of motivations, the wine tourist is someone who mainly has a desire to taste wine and experience the geographic space where the wine is produced (Byrd et al., 2016; Chen, Bruwer, et al., 2016; Cohen \& Ben-Nun, 2009). Motives related to learning about wine, socializing with friends, eating and drinking at the winery, and entertainment are also commonly reported as driving forces to visit the cellar door (Byrd et al., 2016). However, several studies (e.g., Bruwer et al., 2013, 2018; Byrd et al., 2016; George, 2006) confirmed that the need to buy and/or taste wine remain the primary motives of visitation to the cellar door.

Satisfaction has been defined in various ways, but the definition of Oliver (2010) is comprehensive by stating that "satisfaction is the consumer's fulfilment response. It is a judgment that a product/service feature, or the product or service itself, provided (or is providing) a pleasurable level of consumption-related fulfilment, including levels of under- or over fulfilment" (p. 8). Satisfaction has been conceptualized from a number of theoretical perspectives such as overall satisfaction (e.g., Bruwer, 2013), or as a weighted average of satisfaction with the components or attributes of the service or product (e.g., Taplin, 2016). In the current study we conceptualize satisfaction from the "overall" perspective, as no rating of the individual service attributes was sought from the respondents. George (2006) showed that motivations such as wine tasting and wine buying have some influence on satisfaction of visitors to wineries.

Also, the influence of visitor characteristics on satisfaction at the cellar door is inconclusive. While some studies (e.g., Mitchell \& Hall, 2001) showed no gender-based differences on satisfaction with the winery experience, others such as Dodd and Bigotte (1997) showed that older visitors rated several facets of the winery experience differently from younger visitors. Hence, we propose that:

H1: Past wine-related knowledge and behaviors, motivation, and visitor characteristics have an influence on visitor satisfaction at the cellar door.

\section{Past Knowledge and Behaviors, Motivation, Satisfaction, and Actual Behavior}

Empirical findings from past studies show that involvement in wine can predict purchases at the cellar door (Kolyesnikova et al., 2007). Specifically, wine-related knowledge has a positive association with monthly wine expenditures (Mitchell 
\& Hall, 2001). While the study of Alebaki et al. (2015) suggested a potential relationship between wine-related involvement and purchasing behavior at the cellar door, the authors did not empirically confirm this relationship. Bruwer et al. (2012) examined whether previous wine consumption patterns have an influence on the incidence of buying wine, number of bottles bought, and total amount spent on wine at the cellar door. They found that those consuming more than six bottles of wine per month were more likely to engage in the previously mentioned behaviors compared to those who bought less than two bottles. Nonetheless, to date there is no conclusive evidence that past knowledge and behaviors have an influence on the number of bottles of wine bought at the cellar door.

In terms of motivation, Alebaki et al. (2015) showed that involvement in wine and past experience can predict some of the motivations of wine visitors but these authors did not evaluate whether motivation can actually predict purchase behavior on site. Shapiro and Gomez (2014) showed that overall satisfaction has a positive influence on three sales performance measures of cellar doors. Specifically, overall satisfaction has a positive influence on the decision to purchase wine at the cellar door, the amount of money spent, and the number of bottles of wine bought. Likewise, Shapiro and Gomez (2014) showed that age appears to have a significant and positive effect on the number of bottles purchased and the amount of money spent at the winery cellar door. Dodd and Bigotte (1997) found significant differences between older and younger visitors to wineries in their purchasing behavior at the winery, including amount of money spent on wines at the winery, number of wine bottles purchased each month, and money spent on wine per month. In general, older respondents tend to spend and purchase more wine than younger respondents (Bruwer et al., 2012), and there is also a relationship between income and wine consumption (Dodd \& Bigotte, 1997). Hence, we propose that:

H2: Past wine-related knowledge and behaviors, motivation, visitor characteristics, and satisfaction have an influence on actual behavior at the cellar door.

\section{Past Knowledge and Behaviors, Motivation, Satisfaction, Actual Behavior, and Behavioral Intentions}

According to Ajzen (1991), behavioral intentions are assumed to capture the motivational factors that influence behavior. In the wine tourism context, the first visit to a winery's cellar door may constitute the beginning of a relationship, since the opportunity to learn more about the brand can create significant associations with it (Nella \& Christou, 2014). Many wine tourist destinations rely heavily on the repeat visitor segment (Bruwer \& Thach, 2013), and a high incidence of repeat visitation in wine tourism has been confirmed in diverse studies in Canada (Bruwer et al., 2012), South Africa (Bruwer \& Alant, 2009), and Australia (Bruwer \& Gross, 2017). The phenomenon of either a high incidence of first-time or repeat visitation in wine tourism could in some instances be attributed to the spatial relationship (or lack thereof) of the wine region with a big source market, as well as through product-related experiences (Dodd, 1999). Bruwer (2013) found a strong positive relationship between repeat visitation and wine buying in a New Zealand winescape. Byrd et al. (2016) find strong and positive correlations between motives of buying and tasting wine and revisit intentions.

Also, overall satisfaction can be viewed as an affective construct resulting from consumers' holistic appraisal of the performance of a product against their expectations (Parasuraman et al., 1994). Research in the tourism literature has shown consistently that satisfaction influences behavioral intentions (Baker \& Crompton, 2000). Hence, the service tourists receive at the cellar door will affect not only their satisfaction with the experience but also their behavioral intentions (Charters et al., 2009). More specifically, (overall) satisfaction has both direct and indirect effects on behavioral intentions such as revisit intention and positive word-ofmouth (WOM) creation (Nella \& Christou, 2014). Similarly, satisfaction positively influences the future behavioral intentions of wine festival attendees (Bruwer, 2013). Specific to the repurchase intention dimension of wine tourism, researchers have found a positive association between overall customer satisfaction and repurchase intention (Bujisic et al., 2015). The positive relationship 
between overall satisfaction with the cellar door and intentions to revisit the cellar door is also well established (Chen, Goodman, et al., 2016; Park et al., 2019; Stoddard \& Clopton, 2014). However, the relationship between satisfaction with different winery aspects (i.e., services and attributes offered) and repeat visits and repeat purchases of wine at the cellar door has not been deeply tested (Park et al., 2019). In this regard, Stoddard and Clopton (2014) found a positive and significant relationship between repeat visits and satisfaction with both wine quality and tasting room, but no other aspects have been investigated.

Likewise, the influence of wine tourists' characteristics on intended future behavior is inconclusive. For example, despite men purchasing more wine at the cellar door in New Zealand than women, there was no significant gender difference in intended future purchasing behavior (Mitchell \& Hall, 2001). Shapiro and Gomez (2014) found that consumers who were more educated, younger, and female were more likely to purchase wine from the cellar door they had visited. Hence, we propose that:

H3: Past wine-related knowledge and behaviors, motivation, visitor characteristics, satisfaction, and actual behavior at the cellar door have an influence on revisit intentions of wine tourists.

\section{Methodology}

\section{Study Context}

It is estimated that 8.4 million tourists visited Australian wineries in 2018/2019. This represents a sizeable proportion of tourists to Australia, contributing an estimated wine tourism expenditure of AUD \$9.6 billion (Wine Australia, 2020). With the cellar door as an important wine distribution channel in Australia (Gill et al., 2007), both small and large wineries alike are using the cellar door as a unique opportunity to introduce consumers to the winery and its wines (Bruwer et al., 2015). In New World wine country Australia, wine tourism provides employment to 116,000 people: 55,000 directly and 61,000 through flow-on effects (Australian Grape and Wine Authority, 2015).

The Barossa Valley Wine Region in South Australia is Australia's premier wine region and the region of focus of the current study, wherein tourism is a $\$ 235$ million per annum industry, derived from intrastate $(58 \%)$, interstate $(37 \%)$, and international visitors $(5 \%)$ to the region (South Australian Tourism Commission, 2019). The total annual number of day and overnight visitors to the Barossa is $1,187,000$, with an average length of stay of 2.7 nights for overnight visitors (South Australian Tourism Commission, 2019). It is estimated that $41 \%$ of visitors to the Barossa visit a winery cellar door during their visit to the region (Wine Australia, 2020).

\section{Survey Instrument}

This study was a part of a larger project examining the experiences of visitors at cellar doors in Barossa Valley, South Australia. The survey instrument, built from previous studies on wine tourists' behavior and cellar door experiences of visitors to Australia (e.g., Chen, Bruwer, et al., 2016), consisted of several sections. Past knowledge and behaviors (Fig. 1) were measured using two dichotomous (yes/no) questions ["awareness of the winery" and "bought any of the winery's wine(s) in the last 2 months"]. Using two items ("to buy wine" and "to taste wine") on a dichotomous scale (yes/no), adapted from the studies of Bruwer et al. (2012) and López-Guzmán et al. (2014), we measured visitors' motivation of visiting the cellar door. Using the following three questions (number of standard-sized bottles of wine they consume in a typical month, how often they drink wine on a weekly to monthly basis, and how much their household spends on wine in a typical month), we measure respondents' past wine consumption behavior.

Actual behavior at the cellar door is measured using several questions, including whether the visitor tasted wine at the cellar door, number of wines tasted, number of bottles bought at the cellar door, and the total amount of expenditure at the cellar door. As an indicator of postconsumption behavior, overall satisfaction with the cellar door experience was measured with one item ("Was your visit to this cellar door up to your expectations?") on a Likert scale $(1=$ definitely yes to $5=$ definitely not) adapted from previous studies (Bruwer et al., 2013; Chen, Bruwer, et al., 2016; Cohen \& BenNun, 2009). Intention to revisit was measured using 
one item ("willingness to return to the winery in the next 12 months") on a Likert scale ( 1 = definitely yes to $5=$ definitely not) adapted from the study of Chen, Bruwer (2016). Several sociodemographics ware also measured, such as age, gender, education level, state of origin, and annual household income.

\section{Sampling, Data Collection, and Data Analysis}

Of the 70 cellar doors located in the Barossa Valley Wine Region in South Australia, 17 were chosen for data collection purposes. These wineries represent wine operations of different sizes and attract a diverse customer base. At each cellar door, only one respondent from a household participated in the survey. Using a systematic random sampling technique, the target population was identified by staff at the cellar door during different times of the day and days of the week; they waited until the identified persons were ready to depart to hand them the survey. This ensured that visitors had time to reflect on their wine tourism experience as a whole. The surveys were completed in situ and incentives offered in the form of entry in a lucky draw to win a case of the region's best wine. At the end of the data collection period, which lasted 8 weeks in 2016, a total of 814 questionnaires were obtained. However, due to excessive missing data, some questionnaires were eliminated, leading to 676 useable questionnaires.

To analyze the data, three econometric models were estimated. Table 1 schematically describes some of the key features of the three econometric models. For model 1, a logit model allows the assessment of the role of the set of explanatory variables in influencing the probability to be satisfied with the visit. Since the estimated coefficients of each of the independent variables do not have a direct interpretation, as in a linear regression model, the logit transformation is used. This transformation is simply the natural logarithm of the odds (the ratio between the probability of an event to occur and the probability it won't happen). An odds ratio lower than 1 means that a change in one independent variable, holding the other independent variables constant, leads to a reduction in the probability the event occurs (i.e., respondents were definitely satisfied with the visit). Moreover,

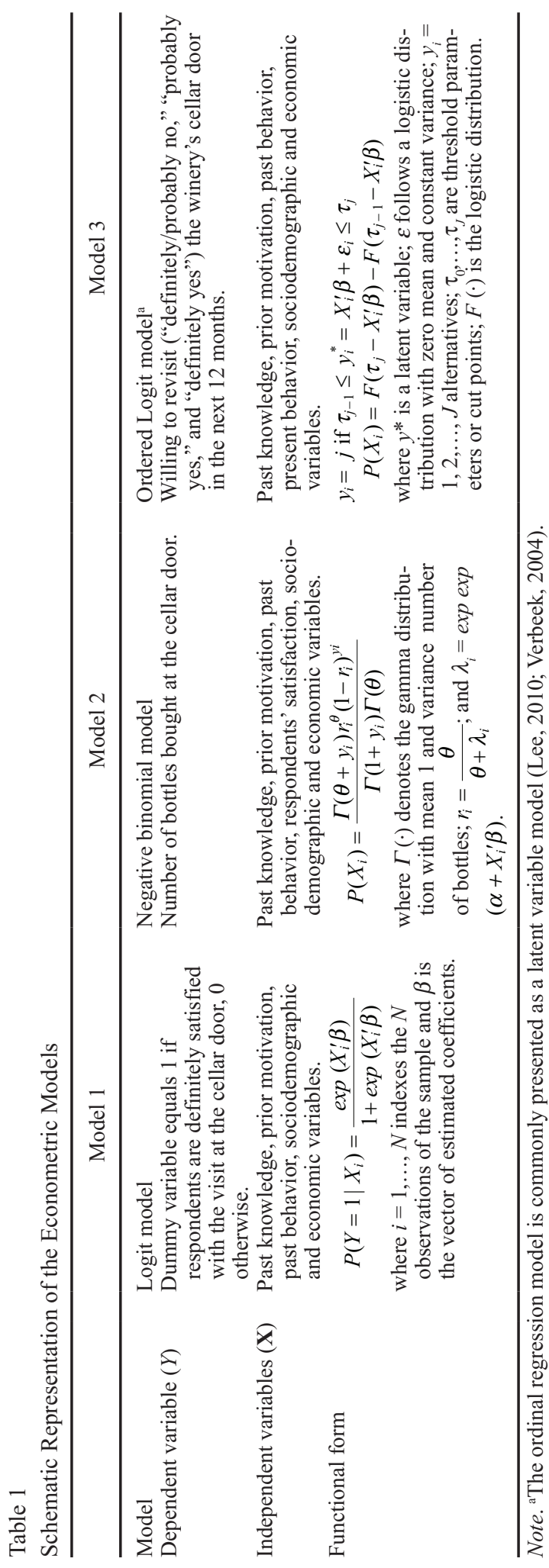


the marginal effect indicates the change in the probability that the respondent was definitely satisfied with the visit due to a unitary change in one of the independent variables calculated at the mean (median).

For model 2 (see Fig. 1), a count model is used to predict actual behavior (number of wine bottles bought at the cellar door). Different count models (Poisson model, negative binomial model, zeroinflated Poisson binomial, zero-inflated truncated negative binomial, zero truncated Poisson, and zero truncated negative binomial model) exist. On the basis of the likelihood ratio test of alpha, Akaike's information criterion (AIC), and Bayesian information criterion (BIC), the negative binomial model has been identified as the best count model for this analysis. Similar to the logit model (model 1), the estimated coefficient does not directly indicate the magnitude of the effect of each of the independent variables on the dependent variable. Therefore, the incidence rate (IRR) is calculated to facilitate interpretation of the final results, and its interpretation is similar to the odds ratio of the logit model. Hence, the marginal effect indicates the change in the estimated number of bottles bought due to a unitary change in one of the independent variables calculated at the mean (median). In model 3, an ordered logit model is estimated to identify the factors that influence the intention to return to the cellar door in the next 12 months. The interpretation is similar to the logit model used for model 1.

\section{Findings}

\section{Demographic Profile of Sample}

The sociodemographic profile of the sample showed that more than half of the visitors to cellar doors in Barossa Valley were males (52.7\%). The sample had a diverse age group distribution (18-28 years, $21.5 \%$; $29-40$ years, $30.9 \%$; $41-54$ years, $28.3 \%$; and 55 years and above, $19.3 \%$ ). In terms of the highest achieved educational level, $61.7 \%$ of the sample had at least a bachelor's degree while the remaining respondents had either a TAFE diploma $(17.2 \%)$ or school leaving certificate $(21.1 \%)$. The majority of visitors were from Australia (84.2\%), with the remaining visitors either from the European Union $(8.6 \%)$ or from other countries $(7.2 \%)$. In terms of the total annual household income level before taxes, the sample was relatively wealthy $(<\$ 50,000$ : $13.3 \% ; \quad \$ 50,001-\$ 75,000$ : $17.1 \%$; $\$ 75,001-\$ 100,000$ : $19.1 \% ; \quad \$ 100,001-\$ 150,000$ : $21 \%$; $\$ 150,000+: 29.4 \%)$.

\section{Relationship Between Past Knowledge and Behaviors, Motivation, Visitor Characteristics, and Satisfaction}

The majority of respondents $(84.40 \%)$ stated that they were satisfied with their visit to the cellar door given that their expectations were met. To identify which factors mainly affect the probability of being satisfied, a binary logit model specified the dependent variable as the recoded satisfaction levels $(0=$ otherwise, $1=$ definitely satisfied) and the independent variables as past behavior (i.e., consumption at home), motivation to visit the cellar door (i.e., to buy or to taste wine), past knowledge about the cellar door and its wines, and sociodemographic variables of the visitors. The results (Table 2) indicated that the higher the monthly household expenditure on wine consumption, the higher the probability that respondents were definitely satisfied with the cellar door visit $(\beta=0.406)$. Conversely, the probability to be definitely satisfied with the visit

Table 2

Determinants of Respondents' Satisfaction With the Cellar Door

\begin{tabular}{lccc}
\hline Independent Variables & $\mathrm{B}$ & Odds Ratio & Marginal Effect \\
\hline Main reason for visiting the cellar door is to taste wine & $-0.775(0.26)^{* * *}$ & 0.461 & -0.079 \\
ln money monthly spent on wine by household & $0.406(0.14)^{* * *}$ & 1.501 & 0.042 \\
Constant & $0.545(0.68)$ & 1.724 & \\
\hline
\end{tabular}

Note. Robust standard errors in parentheses. Number of obs $=612$; Wald $\chi^{2}(2)=14.17$; Prob $>\chi^{2}=>0.001$; McKelvey-Zavoina $R^{2}=0.074$; Log likelihood $=-222.85272$. $* * * p \leq 0.01$. 
decreases when the reason to visit the cellar is to taste wine $(\beta=-0.775)$. Overall, the logit model was able to correctly predict the satisfaction behavior for $87.42 \%$ of the respondents. The model also showed that awareness of the winery and visitor sociodemographics have no influence on satisfaction. Hence H1 was not confirmed.

\section{Relationship Between Past Knowledge and Behaviors, Motivation, Visitor Characteristics, Satisfaction, and Actual Behavior}

During the visit to the cellar door, 55\% of the respondents on average bought five standard bottles of wine $(750 \mathrm{ml})$. The number of bottles bought is specified as the dependent variable in a negative binomial model. The independent variables are past knowledge and behaviors, motivation, visitor characteristics, and actual behavior on site. As reported in Table 3, the number of bottles bought at the cellar door was not significantly affected by past knowledge but was significantly influenced by prior behaviors such as monthly amount of money spent by the household on wine consumption ( $\beta=$ 0.339 ), number of bottles of wine that the respondent personally consumed in a typical month $(\beta=$ $-0.029)$, and motivation $(\beta=0.889)$. Specifically, the number of standard bottles of wine bought at the cellar door significantly increased when the respondent's main reason to visit was to buy wine. $\mathrm{H} 2$ was therefore partially confirmed. The model also showed on-site behaviors, such as number of wines tasted at the cellar door $(\beta=0.151)$, and satisfaction ( $\beta=0.659)$, as well as some sociodemographic characteristics (age, education, and country of origin) can also significantly predict the number of bottles of wine bought at the cellar door. In particular, the higher the number of wines tasted during the visit, the higher the number of standard bottles of wine bought. The more satisfied respondents were with the visit, the more bottles of wine they bought. Also, younger visitors coming from Australia tended to buy a higher number of bottles of wine, while visitors with only a TAFE certificate bought fewer bottles of wines than visitors with a different level of education.

\section{Relationship Between Past Knowledge and Behaviors, Motivation, Visitor Characteristics, Satisfaction, Actual Behavior, and Intention to Revisit}

The sample was almost equally divided between the number of respondents who will probably visit the winery's cellar door again in the future (18\% and 19\% stated "definitely yes" and "probably yes," respectively) and respondents who will not visit again (19\% and 14\% stated "definitely no" and "probably no," respectively). The cut-off point that distinguishes the "definitely no" and the "probably no" responses was not significant, and the following three categories were used in the final model: "Definitely/probably no," "Probably yes," and "Definitely yes." The findings of the ordered logit model (see Table 4) showed that when the main reason to visit the cellar door was to buy wine,

Table 3

Determinants of Respondents' Actual Consumption Behavior at the Cellar Door

\begin{tabular}{lccc}
\hline Independent Variables & B & IRR & Marginal Effect \\
\hline Definitely satisfied with the visit & $0.659(0.20)^{* * *}$ & 1.932 & 1.443 \\
Main reason for visiting the cellar door is to buy wine & $0.889(0.16)^{* * *}$ & 2.433 & 1.949 \\
Number of wines tasted at the cellar door today & $0.151(0.03)^{* * *}$ & 1.164 & 0.332 \\
$l n$ money monthly spent on wine by household & $0.339(0.12)^{* * *}$ & 1.404 & 0.743 \\
Number of standard size bottles personally consumed & $-0.029(0.01)^{* *}$ & 0.972 & -0.063 \\
Less than 34 years old & $0.622(0.15)^{* * *}$ & 1.862 & 1.363 \\
TAFE certificate & $-0.451(0.16)^{* * *}$ & 0.637 & -0.988 \\
Australia & $1.071(0.19)^{* * *}$ & 2.919 & 2.348 \\
Constant & $-3.85(0.53)^{* * *}$ & 0.021 & \\
\hline
\end{tabular}

Note. Robust standard errors in parentheses. Number of obs $=600$; Wald $\chi^{2}(8)=169.39$; Prob $>\chi^{2}=>0.001$; pseudo- $R^{2}=0.0581 ;$ Log pseudolikelihood $=-1193.3382$.

$* * p \leq 0.05, * * * p \leq 0.01$. 
Table 4

Determinants of Visitors' Revisit Intentions to the Cellar Door

\begin{tabular}{lcc}
\hline Independent Variables & $\mathrm{B}$ & Odds Ratio \\
\hline Definitely satisfied with the visit & $0.948(0.29)^{* * *}$ & 2.580 \\
Heard about this winery before & $0.504(0.26)^{*}$ & 1.655 \\
Main reason for visiting the cellar door is to buy wine & $0.654(0.25)^{* *}$ & 1.922 \\
Main reason for visiting the cellar door is to taste wine & $-0.504(0.2)^{* *}$ & 0.604 \\
$\$ 100,001$ to $\$ 150,000$ & $-0.763(0.27)^{* * *}$ & 0.466 \\
$\$ 150,000$ plus & $-0.745(0.22)^{* * *}$ & 0.475 \\
Australia & $1.254(0.38)^{* * *}$ & 3.505 \\
$\tau 1=$ Definitely no/probably no & $2.030(0.50)^{* * *}$ & \\
$\tau 2=$ Probably yes & $3.037(0.50)^{* * *}$ & \\
\hline
\end{tabular}

Note. Robust standard errors in parentheses. Number of obs $=461$; Wald $\chi^{2}(7)=59.92$; Prob $>\chi^{2}=>0.001 ;$ Log pseudolikelihood $=-426.71957$.

$* p \leq 0.1, * * p \leq 0.05, * * * p \leq 0.01$.

the probability to definitely revisit the cellar door increased $(\beta=0.654)$. However, if the respondent mainly visited the cellar to taste wine the probability to revisit the cellar door decreased $(\beta=-0.504)$. This result suggests that the need to buy new wines drives first-time visits to the cellar door, but once respondents have tasted the wine, they have no longer the motivation to come back unless they want to buy wine. Awareness of the cellar door is therefore knowledge that positively affects the intention to revisit the cellar door. According to the results, if the respondents have heard about the cellar door before the visit, they have a higher probability to revisit $(\beta=0.504)$.

Surprisingly, consumption behavior at the cellar door (number of bottles bought or average amount of money spent at the cellar door) did not affect the intention to revisit, while higher satisfaction levels increased the probability to revisit $(\beta=0.948)$. Also, among the sociodemographic variables, household annual income and the country of origin affected the probability to revisit. The higher the household annual income ( $\$ 150,000$ and more), the lower the probability that the visitor will revisit the cellar door $(\beta=-0.745)$. As expected, respondents from Australia were more likely to revisit than visitors from other countries $(\beta=1.254)$. Therefore, $\mathrm{H} 3$ was partially confirmed.

\section{Discussion}

Given the increasing importance of wine tourism for many destinations and the critical role that wine tourism plays in supporting the local economy (Byrd et al., 2016), this study attempts to identify relationships between past knowledge and behaviors related to wine, motivation to visit a cellar door, visitor characteristics, actual-behavior on site, and intention to return. The findings show that overall satisfaction with the cellar door experience is only related to motivation and monthly expenditure on wine consumption. However, number of bottles bought at the winery is predicted by a range of factors including motivation, satisfaction, monthly expenditure on wine consumption, number of bottles personally consumed in a typical month, age, education level, and country of origin of visitors. Also, intention to return to the cellar door is dependent on satisfaction, motivation, income, and awareness of the winery. These findings highlight that different consumer behavior factors impact satisfaction and intentions to return differently. According to the MGB model (Perugini \& Bagozzi, 2001), past behavior, motivational processes, and affective responses can accurately predict decision-making processes. The findings of our study suggest that past behavior (monthly expenditure on wine consumption), motivation (to buy wine), and satisfaction can explain the number of bottles bought at the cellar door. In turn, these variables, along with awareness of the winery, can predict intentions to revisit the winery, thus giving credence to both the proposed tourist behavior model used in this study and the MGB model.

Similar to previous studies (Bruwer et al., 2012), we suggest that previous wine-related consumption 
activities have an influence on wine tourism activity. More specifically we show that monthly expenditure on wine consumption has a direct influence on satisfaction at the cellar door. The identified relationship between motivation and satisfaction of wine tourists conforms to existing studies on the topic (Bruwer \& Alant, 2009; George, 2006). However, we extend previous tourist behavior models incorporating these factors by showing that beyond motivation and satisfaction, number of bottles personally consumed per month has an influence on the number of bottles bought at the cellar door. With the exception of Bruwer et al. (2012), previous studies failed to establish this significant relationship (e.g., Alebaki et al., 2015). However, unlike Bruwer et al. (2012), we show that both the number of wines tasted at the cellar door and the motivation to buy wine are strong drivers of visitors' purchase behavior. Contrary to our expectations, the more wine that a visitor consumed in a typical month, the less likely they were to buy wine at the cellar door. This result may be related to wine connoisseur behaviors, whereby they tend to consume "quality" wines and therefore consume less than the average consumer in a typical month but tend to buy more bottles than the average visitor at the cellar door. It may also be related to their need (motivation) to buy a unique wine that is only available for purchase direct from a winery's cellar door (Bruwer et al., 2018).

Unlike previous studies (Mitchell \& Hall, 2001; Dodd \& Bigotte, 1997), we found no significant difference in satisfaction levels with the cellar door on the basis of sociodemographic characteristics. However, similar to the study of Shapiro and Gomez (2014), we found that overall satisfaction has an influence on number of wine bottles bought at the cellar door. Moreover, age and education level are significant determinants of the number of wine bottles bought. Thus, we provide some evidence that younger respondents buy more, in contradiction to several existing studies (Bruwer et al., 2012; Dodd \& Bigotte, 1997; Shapiro \& Gomez, 2014), but we confirm that the more educated the visitors are, the more bottles they tend to purchase. This perhaps highlights the significant change in the profile of visitors to cellar doors in South Australia, with younger visitors buying more if they are from the region/country, and also possibly displaying risk reduction behavior, in the sense that they are buying wine in an environment where more information is available, as opposed to a retail store.

Given that the future of cellar doors is much dependent on wine tourists' repeat behavior (Bruwer et al., 2015; Bruwer et al., 2012; Chen, Bruwer, et al., 2016), the findings of this study show that an awareness of the cellar door is critical for positive intention to return but not for satisfaction. As such, we extend the study of S. Lee et al. (2017) that could not establish the influence of past knowledge and behavior on behavioral intention. Specifically, we confirm that motivation and overall winery experience satisfaction have an influence on revisit intention to the cellar door as suggested in previous studies (Byrd et al., 2016; Chen, Goodman, et al., 2016; Nella \& Christou, 2014; Park et al., 2019; Stoddard \& Clopton, 2014). However, unlike Bruwer (2013), we could not establish the link between the number of wine bottles bought and intention to revisit. This may be due to the fact that, on their current visit, the visitor has already bought the desired number bottles from (an)other winery(ies) in the region that will go towards future consumption, or they will buy the wine(s) of the cellar door from retail outlets, and hence do not need to revisit the winery.

\section{Managerial Implications}

For cellar door managers, it is important to provide a memorable cellar door experience to establish a long-term relationship with cellar door visitors (Bruwer \& Alant, 2009). Our findings suggest that previous wine-related knowledge (prior awareness of the cellar door) has an impact on revisit intention. Thus, communication campaigns of cellar doors must focus on creating awareness of the cellar door and its wines to encourage not only trial but also repeat purchase. The study shows the actual value of using the cellar door as an opportunity to understand how past behavior shapes and informs intention to return. More importantly, for cellar door managers, it shows how past behavior (number of bottles consumed and monthly expenditure on wine consumption) impacts the number of wines tasted and purchased at the winery. This has financial implications in terms of revenue generation for the cellar door, with clear segmentation implications in 
the sense that cellar door managers need to identify segments of consumers that generally spend more on wine as a household and visitors that personally consume more that the average consumer.

The findings also suggest the potential for the cellar door to act as a catalyst for future sales if the motivation of the buyer is well understood (Bruwer et al., 2018). Understanding the motivation and revisit intentions of visitors to cellar doors is a fundamental element of developing successful destination marketing strategies for wineries and wine regions (Byrd et al., 2016). According to the findings, if the main reason is to taste wine, the visitor is less likely to be satisfied. Hence, the need for cellar doors to cross-sell other experiences, such as those related to food and merchandising opportunities, rather than solely focusing on wine tasting, but also the need to emphasize other attractions and activities to partake of in the region to encourage repeat visitation. The cellar door provides a winery and its brand with an opportunity to satisfy visitors, which in turn leads to customers actively seeking out a winery's products in the retail sector and generates positive intentions to revisit (Bruwer et al., 2013). The findings highlight the need to target young and older consumers differently. According to the findings, younger consumers from Australia are likely to buy more bottles, with more educated consumers also likely to engage in such behaviors. Hence, a generic strategy would be less effective at both attracting and retaining these two segments of the market.

\section{Limitations and Future Research}

Although this study has provided insights into the role and influence of past wine-related knowledge and behaviors, satisfaction, and actual behavior at the cellar door on revisit intentions, it is not without limitations. First, the two most relevant motives (to buy and taste wine) are considered in our study. Previous studies (Alant \& Bruwer, 2004; Byrd et al., 2016) suggested that there could be other motives that combine with the primary motives of tasting and buying wine to drive the visit to the cellar door, and hence these could be included in predictive models of behavioral intentions. Second, overall satisfaction was measured instead of attributebased satisfaction. Previous studies (Chen, Bruwer, et al., 2016; Dodd \& Bigotte, 1997; Mitchell \& Hall, 2001) have shown that the cellar door environment is multifaceted. Therefore, future research should examine satisfaction with each aspect of the cellar door environment in predicting behavioral intentions. Third, cross-sectional data are used to predict intention to revisit. Longitudinal studies must be undertaken to better assess the relationships between past behavior, satisfaction, actual consumption, and revisit and repurchase intentions at cellar doors and elsewhere. Fourth, our study was limited to Australia and to a single wine region, and therefore, to be able to generalize the findings, other studies in different wine regions across the world could replicate our research.

\section{References}

Ajzen, I. (1991). The theory of planned behavior. Organizational Behavior and Human Decision Processes, 50(2), 179-211.

Alant, K., \& Bruwer, J. (2004). Wine tourism behaviour in the context of a motivational framework for wine regions and cellar doors. Journal of Wine Research, 15(1), $27-37$.

Alant, K., \& Bruwer, J. (2010). Winery visitation sets: Intra-regional spatial movements of wine tourists in branded regions. International Journal of Wine Business Research, 22(2), 191-210.

Alebaki, M., Menexes, G., \& Koutsouris, A. (2015). Developing a multidimensional framework for wine tourist behavior: Evidence from Greece. Wine Economics and Policy, 4(2), 98-109.

Alén, E., Nicolau, J. L., Losada, N., \& Domínguez, T. (2014). Determinant factors of senior tourists' length of stay. Annals of Tourism Research, 49, 19-32.

Australian Grape and Wine Authority. (2015). Economic contribution of the Australian wine sector. AgEconPlus Consulting and Gillespie Economics.

Baker, D. A., \& Crompton, J. L. (2000). Quality, satisfaction and behavioral intentions. Annals of Tourism Research, 27(3), 785-804.

Belk, R. W., Ger, G., \& Askegaard, S. (2003). The fire of desire: A multisited inquiry into consumer passion. Journal of Consumer Research, 30(3), 326-351.

Bruwer, J. (2013). Service quality perception and satisfaction in a New Zealand festivalscape: Buying behavior effects. Tourism Analysis, 18(1), 61-77.

Bruwer, J., \& Alant, K. (2009). The hedonic nature of wine tourism consumption: An experiential view. International Journal of Wine Business Research, 21(3), 235-257.

Bruwer, J., Coode, M., Saliba, A. J., \& Herbst, F. (2013). Wine tourism experience effects of the tasting room on consumer brand loyalty. Tourism Analysis, 18(4), 399-414. 
Bruwer, J., \& Gross, M. J. (2017). A multilayered macro approach to conceptualizing the winescape construct for wine tourism. Tourism Analysis, 22(4), 497-509.

Bruwer, J., Lesschaeve, I., \& Campbell, B. L. (2012). Consumption dynamics and demographics of Canadian wine consumers: Retailing insights from the tasting room channel. Journal of Retailing and Consumer Services, 19(1), 45-58.

Bruwer, J., Lockshin, L., Saliba, A. J., \& Hirche, M. (2015). Cellar door: Trial-purchase-repurchase of the brand: How does a cellar door visit impact future sales? Wine \& Viticulture Journal, 30(1), 56-59.

Bruwer, J., Prayag, G., \& Disegna, M. (2018). Why wine tourists visit cellar doors: Segmenting motivation and destination image. International Journal of Tourism Research, 20(3), 355-366.

Bruwer, J., \& Thach, L. (2013). Wine tourists' use of sources of information when visiting a USA wine region. Journal of Vacation Marketing, 19(3), 221-237.

Bujisic, M., Bilgihan, A., \& Smith, S. (2015). Relationship between guest experience, personality characteristics, and satisfaction: Moderating effect of extraversion and openness to experience. Tourism Analysis, 20(1), 25-38.

Byrd, E. T., Canziani, B., Hsieh, Y. C. J., Debbage, K., \& Sonmez, S. (2016). Wine tourism: Motivating visitors through core and supplementary services. Tourism Management, 52, 19-29.

Charters, S., Fountain, J., \& Fish, N. (2009). "You felt like lingering ....": Experiencing "real" service at the winery tasting room. Journal of Travel Research, 48(1), 122-134.

Chen, X., Bruwer, J., Cohen, J., \& Goodman, S. (2016). A wine tourist behavior model for Australian winery cellar doors. Tourism Analysis, 21(1), 77-91.

Chen, X., Goodman, S., Bruwer, J., \& Cohen, J. (2016). Beyond better wine: The impact of experiential and monetary value on wine tourists' loyalty intentions. Asia Pacific Journal of Tourism Research, 21(2), 172-192.

Cohen, E., \& Ben-Nun, L. (2009). The important dimensions of wine tourism experiencefrom potential visitors' perception. Tourism and Hospitality Research, 9(1), 20-31.

Dodd, T. H. (1999). Attracting repeat customers to wineries. International Journal of Wine Marketing, 11(2), 18-27.

Dodd, T. H., \& Bigotte, V. (1997). Perceptual differences among visitor groups to wineries. Journal of Travel Research, 35(3), 46-51.

Dolnicar, S., Coltman, T., \& Sharma, R. (2015). Do satisfied tourists really intend to come back? Three concerns with empirical studies of the link between satisfaction and behavioral intention. Journal of Travel Research, 54(2), 152-178.

Fountain, J., Fish, N., \& Charters, S. (2008). Making a connection: Tasting rooms and brand loyalty. International Journal of Wine Business Research, 20(1), 8-21.

George, B. P. (2006). Wine tourist motivation and the perceived importance of servicescape: A study conducted in Goa, India. Tourism Review, 61(3), 15-19.
Gill, D., Byslma, B., \& Ouschan, R. (2007). Customer perceived value in a cellar door visit: The impact on behavioural intentions. International Journal of Wine Business Research, 19(4), 257-275.

Kolyesnikova, N., Dodd, T. H., \& Laverie, D. A. (2007). Gratuity purchasing at wineries: An investigation of the determining factors. International Journal of Wine Business Research, 19(4), 239-256.

Lee, J. (2010). The link between output growth and volatility: Evidence from a GARCH model with panel data. Economics Letters, 106(2), 143-145.

Lee, S., Bruwer, J., \& Song, H. (2017). Experiential and involvement effects on the Korean wine tourist's decision-making process. Current Issues in Tourism, 20(12), 1215-1231.

Liang, S., Schuckert, M., Law, R., \& Chen, C. C. (2017). Be a "Superhost": The importance of badge systems for peer-to-peer rental accommodations. Tourism Management, 60, 454-465.

López-Guzmán, T., Vieira-Rodríguez, A., \& RodríguezGarcía, J. (2014). Profile and motivations of European tourists on the Sherry wine route of Spain. Tourism Management Perspectives, 11, 63-68.

McKercher, B., \& Tse, T. S. M. (2012). Is intention to return a valid proxy for actual repeat visitation? Journal of Travel Research, 51(6), 671-686.

Mitchell, R., \& Hall, C. M. (2001). The influence of gender and region on the New Zealand winery visit. Tourism Recreation Research, 26(2), 63-75.

Nella, A., \& Christou, E. (2014). Linking service quality at the cellar door with brand equity building. Journal of Hospitality Marketing and Management, 23(8), 699-721.

Oliver, R. L. (2010). Satisfaction: A behavioral perspective on the consumer ( 2 nd ed.). M. E. Sharpe.

Parasuraman, A., Zeithaml, V. A., \& Berry, L. L. (1994). Reassessment of expectations as a comparison standard in measuring service quality: Implications for further research. Journal of Marketing, 58(1), 111-124.

Park, J.-Y., Bufquin, D., \& Back, R. M. (2019). When do they become satiated? An examination of the relationships among winery tourists' satisfaction, repeat visits and revisit intentions. Journal of Destination Marketing \& Management, 11, 231-239.

Perugini, M., \& Bagozzi, R. P. (2001). The role of desires and anticipated emotions in goal-directed behaviours: Broadening and deepening the theory of planned behaviour. British Journal of Social Psychology, 40(1), 79-98.

Shapiro, M. I., \& Gómez, M. (2014). Customer satisfaction and sales performance in wine tasting rooms. International Journal of Wine Business Research, 26(1), 45-60.

Stoddard, J. E., \& Clopton, S. W. (2014). Exploring the differences between new and repeat visitors to North Carolina wineries: Implications for winery marketing strategy development. Journal of Wine Research, 26(3), 225-240. 
South Australian Tourism Commission. (2019). Barossa regional profile. https://tourism.sa.gov.au/media/gxsanddp/ barossa_dec19.pdf

Sparks, B. (2007). Planning a wine tourism vacation? Factors that help to predict tourist behavioural intentions. Tourism Management, 28(5), 1180-1192.

Taplin, R. H. (2016). Reconceptualizing overall visitor satisfaction as an average of satisfaction with attributes. Tourism Analysis, 21(5), 529-540.
Verbeek, M. (2004). A guide to modern econometrics. John Wiley \& Sons.

Wang, E., Wei, J., \& Zhu, J. (2017). The effects of improving coastal park attributes on the recreation demand: A case study in Dalian China. Tourism Economics, 23(1), 133-149.

Wine Australia. (2020). Wine Australia providing insights on Australian wine: Wine tourism snapshot 2018-19. https:// www.wineaustralia.com/market-insights/australianwine-tourism-snapshot 
Copyright of Tourism Analysis is the property of Cognizant, LLC and its content may not be copied or emailed to multiple sites or posted to a listserv without the copyright holder's express written permission. However, users may print, download, or email articles for individual use. 